\title{
Isolation of Tibet Orbivirus from Culicoides jacobsoni (Diptera, Ceratopogonidae) in China
}

\author{
Ying Liang Duan ${ }^{1 \dagger}$, Zhen Xing Yang ${ }^{1 \dagger}$, Glenn Bellis ${ }^{2,3}$ and Le Li ${ }^{1 *}$
}

\begin{abstract}
Background: Tibet Orbivirus (TIBOV) is a recently discovered Orbivirus known to infect cattle, Asian buffalo and goats in south-western China. It was first isolated from mosquitoes and subsequently from biting midges (Culicoides spp.) in Yunnan, China, indicating that it is an arbovirus. Little is known of its potential to cause disease, but the economic importance of related viruses promoted an investigation of potential Culicoides spp. vectors of TIBOV.

Methods: Biting midges were collected approximately once per week between May and December 2020, at a cattle farm in Wulong village, Shizong County, Yunnan Province, China. Approximately 3000 specimens of nine species were subsequently used in attempts to isolate virus, and a further 2000 specimens of six species were tested for the presence of bluetongue virus (BTV) and TIBOV using a RT-qPCR test.

Results: Virus isolation attempts resulted in the isolation of three viruses. One isolate from a pool of Culicoides jacobsoni was identified as TIBOV, while the other two viruses from C. orientalis and C. tainanus remain unidentified but are not BTV or TIBOV. RT-qPCR analysis did not detect BTV in any specimens, but a single pool containing five specimens of $C$. jacobsoni and another containing five specimens of $C$. tainanus produced PCR quantification cycle (Cq) values of around 28 that may indicate infection with TIBOV.

Conclusions: The isolation of TIBOV from C. jacobsoni satisfies one criterion required to prove its status as a vector of this virus. This isolation is supported by a low Cq value produced from a different pool of this species in the RT-qPCR test. The low Cq value obtained from a pool of C. tainanus suggests that this species may also be able to satisfy this criterion. Both of these species are widespread throughout Asia, with C. jacobsoni extending into the Pacific region, which raises the possibility that TIBOV may be more widespread than is currently known.
\end{abstract}

Keywords: Culicoides, C. jacobsoni, C. tainanus, Tibet Orbivirus, China

\section{Background}

Seven taxonomic families of double-strand (ds)RNA viruses are currently recognized, of which only species of Reoviridae are known to infect mammals [1]. Viruses belonging to this family are characterized by possessing multiple dsRNA fragments and double layers of capsids and have been placed into two subfamilies and 15 genera

\footnotetext{
*Correspondence: htmlile@outlook.com

${ }^{\dagger}$ Ying Liang Duan and Zhen Xing Yang contributed equally to this work ${ }^{1}$ Yunnan Tropical and Subtropical Animal Virus Diseases Laboratory, Yunnan Animal Science and Veterinary Institute, Kunming, Yunnan, China Full list of author information is available at the end of the article
}

$[1,2]$. One of these genera, Orbivirus, includes 22 species ratified by the International Committee on Taxonomy of Viruses (2020) [2,3] and includes the most economically important species in the family, including bluetongue virus (BTV) and African horse sickness virus (AHSV) [4, 5]. It is notable that the economic importance of many of the other species of genus Orbivirus remains unknown.

A novel species of Orbivirus, Tibet Orbivirus (TIBOV), was isolated relatively recently, in 2009, from Anopheles maculatus in Medog County in the Nyingchi area of Tibet, China, making it the 23rd species in genus Orbivirus [6]. However, a virus had been isolated from Culex tritaeniorhynchus in 2007, although it was not identified original author(s) and the source, provide a link to the Creative Commons licence, and indicate if changes were made. The images or other third party material in this article are included in the article's Creative Commons licence, unless indicated otherwise in a credit line to the material. If material is not included in the article's Creative Commons licence and your intended use is not permitted by statutory regulation or exceeds the permitted use, you will need to obtain permission directly from the copyright holder. To view a copy of this licence, visit http://creativecommons.org/licenses/by/4.0/. The Creative Commons Public Domain Dedication waiver (http://creativeco mmons.org/publicdomain/zero/1.0/) applies to the data made available in this article, unless otherwise stated in a credit line to the data. 
as TIBOV at that time or reported until 2017 [7]; consequently, 2007 is actually the earliest known occurrence of this virus. TIBOV was subsequently isolated from unidentified Culicoides from Yunnan Province, China [8, 9], supporting its status as an arbovirus. A limited investigation in Yunnan Province found relatively high antibody prevalence rates in cattle and Asian buffalo and lower rates in goats, indicating that these species are mammalian hosts of this virus [9]. The infection of bovids with TIBOV introduces the possibility that this virus could be a potential pathogen for these or other vertebrate species, as has been shown for other Orbivirus such as BTV [1, 10].

The genus Culicoides (Diptera: Ceratopogonidae) has been implicated in the transmission of several species of Orbivirus [10,11], strongly suggesting that species in this genus should be considered as possible vectors of TIBOV. At least 40 species of Culicoides are currently known to be vectors or potential vectors of pathogens, including at least 50 species of arboviruses [12, 13]. Identification of the vectors is a vital step in understanding the epidemiology of arboviruses, with those causing animal diseases of particular importance. Proven vectors of an arbovirus must satisfy four criteria, two of which are the recovery of virus from wild-caught specimens and an accumulation of field evidence confirming the significant association of the infected arthropods with the appropriate vertebrate population in which disease or infection is occurring $[4,5]$. Recently, Culicoides tainanus and $C$. jacobsoni, both of which are common and widespread species of biting midges in Asia, were reported as satisfying these two criteria with respect to BTV in Yunnan Province, China $[14,15]$, suggesting the potential of these species to be involved with other Orbivirus, particularly viruses associated to bovids. In this study, the potential Culicoides vectors of TIBOV were studied in Shizong, Yunnan Province, China.

\section{Methods \\ Culicoides spp. collection and sorting}

Biting midges were collected one night per week for most weeks between May and December 2020 (Table 1), inside a shed containing four penned cattle located in Wulong village, Shizong County, Yunnan Province, China $\left(24^{\circ} 63^{\prime} \mathrm{N}, 104^{\circ} 29^{\prime} \mathrm{E}\right)$. A single battery-powered UV light trap (LTS-M02; Wuhan Lucky Star Medical Treatment Technology Co., Wuhan, China) was run from 17:00 h to 09:00 $\mathrm{h}$ the following day. Midges were collected directly into phosphate-buffered saline (PBS) (May to November) or $70 \%$ ethanol (December) and transported without refrigeration to the laboratory within $24 \mathrm{~h}$ of collection. Culicoides were sorted by gross morphology and wing pattern [16-18], then parous female specimens without blood meal were washed once in PBS and kept at $4{ }^{\circ} \mathrm{C}$ in either PBS containing two antibiotics $(100 \mathrm{U} / \mathrm{ml}$ ampicillin and $0.1 \mathrm{mg} / \mathrm{ml}$ streptomycin; referred to further as $\mathrm{PBS}+$ double antibiotics) $\left(\right.$ Gibco $^{\mathrm{TM}}$, Thermo Fisher Scientific, Waltham, MA, USA) for viral isolation or in $75 \%$ ethanol for PCR analysis. All species that were collected in sufficient numbers were tested, with a particular focus on C. tainanus and C. jacobsoni as they have been recently reported as potential vectors of BTV in China and Asia $[14,15,19]$.

\section{Competitive enzyme-linked immunosorbent assay for cattle blood}

Serum samples were collected from the four penned cattle once per week between May and October in 2020. A competitive enzyme-linked immunosorbent assay (C-ELISA) was used to detect BTV antibody in these sera [20].

\section{Virus isolation}

For virus isolation, collected Culicoides were placed into pools of no more than 100 conspecific specimens, washed once in $1 \mathrm{ml} \mathrm{PBS}+$ double antibiotics $\left(\mathrm{Gibco}^{\mathrm{TM}}\right.$, Thermo Fisher Scientific) and suspended in $1 \mathrm{ml}$ minimum essential medium (MEM; Gibco ${ }^{\mathrm{TM}}$ ) + double antibiotics. Pools were homogenized using a multiple functional homogenizer TissueLyser II (Qiagen, Hilden, Germany) for three cycles of 30 pulses per second for $45 \mathrm{~s}$ with an interval of $5 \mathrm{~s}$ between cycles. Homogenized samples were centrifuged at $12,000 \mathrm{rpm}$ at $4{ }^{\circ} \mathrm{C}$ for $20 \mathrm{~min}$, and $400-\mu \mathrm{l}$ aliquots of supernatant were inoculated onto baby hamster Syrian kidney cell line BHK-21 or Aedes albopictus cell line C6/36, respectively. Cells were cultured and monitored as described by $\mathrm{Li}$ et al. [6]. The supernatants collected from cultures with a cytopathic effect (CPE) were stored at $-80^{\circ} \mathrm{C}$.

\section{Pooling of specimens for nucleic acid extraction and testing for the presence of viruses}

Pools submitted for nucleic acid extraction comprised specimens belonging to a single species. Specimens were digested either individually (to confirm prescence of cytochrome $c$ oxidase subunit 1 [cox1]) or in pools of five conspecific specimens (to detect virus). For virus detection, an aliquot of lysate was taken from eight of these pools.

\section{Nucleic acid extraction}

Prepared Culicoides specimens were submitted for nondestructive nucleic acid extraction using a procedure described by Duan et al. [14, 15]. Briefly, midges were incubated in $50 \mu \mathrm{l}$ of lysis buffer from a Genomic DNA Extraction kit (TIANGEN, Beijing, China) at $30{ }^{\circ} \mathrm{C}$ for 
Table 1 Relative seasonal abundance of Culicoides tainanus and C. jacobsoni in light traps set in a cattle shed in Shizong, Yunnan Province, China between May and December 2020

\begin{tabular}{|c|c|c|c|c|c|}
\hline \multirow[t]{2}{*}{ Date $^{a}$} & \multirow[t]{2}{*}{ Weather ${ }^{b}$} & \multirow[t]{2}{*}{ Temperature $\left({ }^{\circ} \mathrm{C}\right)$} & \multicolumn{3}{|c|}{ Number of biting midges collected (\%) } \\
\hline & & & All specimens & Culicoides tainanus & Culicoides jacobsoni \\
\hline 20 May & Cloudy/sunny & $19-29$ & 394 & $226(57.4)$ & $0(0)$ \\
\hline 25 May & Overcast/light rain & $12-23$ & 1330 & $291(21.9)$ & $2(0.2)$ \\
\hline 05 June & Overcast/light rain & $17-28$ & 275 & $78(28.4)$ & $0(0)$ \\
\hline 09 June & Cloudy/light rain & $17-24$ & 1756 & $644(36.7)$ & $2(0.1)$ \\
\hline 17 June & Overcast & $18-25$ & 924 & $301(32.6)$ & $9(1.0)$ \\
\hline 07 July & Cloudy/light rain & $19-27$ & 10 & $2(20.0)$ & $0(0)$ \\
\hline 14 July & Overcast & $17-26$ & 203 & $61(30.0)$ & $26(12.8)$ \\
\hline 21 July & Cloudy & $17-23$ & 282 & $102(36.2)$ & $6(2.1)$ \\
\hline 28 July & Sunny/light rain & $14-25$ & 19 & $5(26.3)$ & $7(36.8)$ \\
\hline 04 August & Light rain & $17-24$ & 1894 & $487(25.7)$ & $213(11.2)$ \\
\hline 12 August & Overcast/light rain & $18-26$ & 416 & $43(10.3)$ & $16(3.8)$ \\
\hline 08 September & Cloudy/shower & $17-24$ & 1847 & $343(18.6)$ & $178(9.6)$ \\
\hline 15 September & Shower & ND & 2057 & $38(1.8)$ & $19(0.9)$ \\
\hline 22 September & Shower/light rain & ND & 954 & $91(9.5)$ & $222(23.3)$ \\
\hline 28 September & Shower & ND & 401 & $50(12.5)$ & $93(23.2)$ \\
\hline 13 October & Cloudy & ND & 245 & $24(9.8)$ & $32(13.1)$ \\
\hline 20 October & Light rain & ND & 1788 & $674(37.7)$ & $101(5.6)$ \\
\hline 27 October & Cloudy/light rain & ND & 1723 & $601(34.9)$ & $31(1.8)$ \\
\hline 03 November & Light rain & ND & 270 & $65(24.1)$ & $37(13.7)$ \\
\hline 18 November & Cloudy/sunny & ND & 507 & $358(70.6)$ & $21(4.1)$ \\
\hline 02 December & Light rain & ND & 461 & 404 (87.6) & $3(0.7)$ \\
\hline 11 December & Cloudy & ND & 493 & $389(78.9)$ & $3(0.6)$ \\
\hline 20 December & Sleet & ND & 21 & $18(85.7)$ & $0(0)$ \\
\hline Total & & & 18,270 & 5295 (29.0\%) & $1021(5.6 \%)$ \\
\hline
\end{tabular}

$N D$ the data were not detected

${ }^{a}$ Colllection date

${ }^{\mathrm{b}}$ The weather on the dates traps were set and midges collected

$16 \mathrm{~h}$. The DNA and RNA were extracted together using a MagMAX ${ }^{\mathrm{TM}}-96$ Viral RNA Isolation kit following the manufacturer's directions and a MagMAX ${ }^{\mathrm{TM}}$ Express-96 magnetic particle processor (both Ambion Inc., Thermo Fisher Scientific). Nucleic acids were eluted with $50 \mu \mathrm{l}$ of elution buffer and stored at $-20^{\circ} \mathrm{C}$. A similar procedure was followed to extract RNA from $50 \mu \mathrm{l}$ of supernatant obtained from BHK-21 or C6/36 cells with CPEs caused by infection with viruses isolated from collected Culicoides specimens.

For TIBOV strain identification, a T75 flask of mock (supernatant from regular cell culture used as negative control) or viral isolate-infected BHK-21 cells at $72 \mathrm{~h}$ post-infection [hpi]) was scraped and the recovered cells centrifuged at $360 \mathrm{~g}$ for $5 \mathrm{~min}$. The cell pellets were then transferred to $1.5-\mathrm{ml}$ tubes, suspended in approximately $100 \mu \mathrm{l}$ supernatant and lysed by freezing and thawing twice, followed by incubation with $25 \mathrm{U}$ of recombinant DNase I (Takara Bio, Osaka, Japan), $50 \mu$ g RNase
A (Takara Bio) and $100 \mathrm{U}$ of Cryonase ${ }^{\mathrm{TM}}$ Cold-active Nuclease (Takara Bio) at $37^{\circ} \mathrm{C}$ for $16 \mathrm{~h}$ [20]. This process resulted in cellular DNA and RNA being removed while the viral genomes of the virions remained conserved within their capsid. Total RNA was then extracted by a method modified from the common manual method [21]. Briefly, each sample was lysed by $1.2 \mathrm{ml}$ Trizol (Invitrogen ${ }^{\circledR}$, Thermo Fisher Scientific, Waltham, MA, USA) and incubated at room temperature (RT) for $10 \mathrm{~min}$, then mixed with $220 \mu \mathrm{l}$ chloroform and incubated at RT for $3 \mathrm{~min}$. The supernatant (about $1 \mathrm{ml}$ per sample) was collected and centrifuged at $13,000 \mathrm{~g}$ at $4{ }^{\circ} \mathrm{C}$ for $10 \mathrm{~min}$, mixed with an equal volume of isopropanol, then incubated at RT for $15 \mathrm{~min}$. RNA was deposited by centrifugation $\left(13000 \mathrm{~g}, 4{ }^{\circ} \mathrm{C}, 10 \mathrm{~min}\right)$ and washed once in $1 \mathrm{ml}$ of cold $75 \%$ ethanol. Deposited RNA was air dried at RT and suspended in $20 \mu \mathrm{l}$ of RNase-free water. 


\section{Reverse transcription-quantitative PCR}

Specimens from the six most abundant species collected were tested for the presence of TIBOV and BTV by reverse transcription-quantitative PCR (RT-qPCR). First, pools of five conspecific specimens were digested together, then a $10-\mu \mathrm{l}$ aliquot of lysate was taken from eight of these pools and mixed together to form $80 \mu \mathrm{l}$ of mixed lysate, representing 40 specimens, for preliminary testing by RT-qPCR. A 2- $\mu$ l aliquot of RNA was taken from each 80- $\mu$ l mixed lysate and submitted for RT-qPCR processing using primers and 6-carboxy-fluorescein (FAM) conjugated probes (Table 2) targeting Seg9 of TIBOV, as described by Yang et al. [22]. Samples with a quantification cycle $(\mathrm{Cq})$ value $<40$ in the RTqPCR potentially contain positive samples so these were tested further to ascertain which of the eight pools in the mixture contained the potentially infected insect. A 2- $\mathrm{ll}$ aliquot of RNA extracted from each of the eight pools that comprised the potentially positive large pools was processed individually using the same RT-qPCR. A One Step PrimeScript ${ }^{\text {TM }}$ RT-PCR kit (Takara Bio) was used to confect the reaction solution and the reaction was performed as described by the manufacturer using a 2- $\mu \mathrm{l}$ RNA sample in a total volume of $20 \mu \mathrm{l}$. RT-qPCR was performed on a Fast7500 Realtime PCR system (Applied Biosystems $^{\mathrm{TM}}$, Thermo Fisher Scientific) with the following cycling conditions: reverse transcription at $42{ }^{\circ} \mathrm{C}, 4$ min; then denaturation at $92{ }^{\circ} \mathrm{C} / 10 \mathrm{~s}$; followed by denaturation at $92{ }^{\circ} \mathrm{C} / 5 \mathrm{~s}$ and annealing-extension at $60{ }^{\circ} \mathrm{C} / 34$ $\mathrm{s}$ for 40 cycles. Fluorescence was measured at the end of each extension step. Positive controls with a Cq between 23 and 25, and a negative control (water) without signal were run with each batch tested.

The presence of BTV RNA was tested in the same pools of insect lysate using a pan BTV serotype RT-qPCR method [15] with primers BTVF-MH and BTVR-MH and probe BTVP-MH [23]. Properly diluted positive controls with a Cq of approximately 25 and a negative control (water) without signal were run with each batch tested.

\section{Reverse transcription for viral RNA}

The cDNA of viral RNA was synthesized using the kit of the SuperScript ${ }^{\circledR}$ III First-Strand Synthesis System (Invit$\operatorname{rogen}^{\mathrm{TM}}$, Thermo Fisher Scientific) according to the manufacturer's instructions. Briefly, $8 \mu \mathrm{l}$ of RNA was mixed with $1 \mu \mathrm{l}$ dNTPs and $1 \mu \mathrm{l}$ random primers provided by the kit, then denatured at $95{ }^{\circ} \mathrm{C}$ for $1 \mathrm{~min}$ followed by quick cooling on ice. Buffers and reverse transcriptase (RTase) were added, and a total of $20 \mu \mathrm{l}$ cDNA per sample was produced by a RT process: incubation at $25^{\circ} \mathrm{C} / 10$ min, $45^{\circ} \mathrm{C} / 30 \mathrm{~min}$ and $85{ }^{\circ} \mathrm{C} / 5 \mathrm{~min}$; then temporary storage at $4{ }^{\circ} \mathrm{C}$. Following the temporary storage, $1 \mu \mathrm{l}$ ribonuclease $\mathrm{H}$ was added followed by incubation at $37^{\circ} \mathrm{C}$ for 10 min to delete the RNA.

\section{PCR for TIBOV}

Primers targeting three separate TIBOV genes (Table 2) were used to amplify viral genes. For each test, $0.5 \mu \mathrm{l}$ of cDNA was added to $9.5 \mu \mathrm{l}$ PCR solution which was confected with primers and Taq-PCR premix (TIANGEN). For sequencing, $3 \mu \mathrm{l}$ of cDNA was used in a $50-\mu \mathrm{l}$ reaction system confected with primers and PrimeSTAR ${ }^{\circledR} \mathrm{HS}$ premix (Takara Bio). The PCR cycling program consisted of: denaturation at $95{ }^{\circ} \mathrm{C}, 2 \mathrm{~min}$; denaturation at $95{ }^{\circ} \mathrm{C} / 10$ $\mathrm{s}$, annealing at $54{ }^{\circ} \mathrm{C} / 10 \mathrm{~s}$, extension at $72{ }^{\circ} \mathrm{C} / 1 \mathrm{~min}$ (Taq) or at $68{ }^{\circ} \mathrm{C} / 1 \mathrm{~min}$ (PrimeSTAR) for 30 cycles; and a final extension at $72{ }^{\circ} \mathrm{C}$ or $68{ }^{\circ} \mathrm{C}$ for $1 \mathrm{~min}$, with storage at $4{ }^{\circ} \mathrm{C}$.

\section{PCR for cox 1 amplification}

All specimens submitted for cox 1 amplification were processed individually. A 5.5- $\mu \mathrm{l}$ aliquot of nucleic acid from

Table 2 Primers and probes used to target Tibet Orbivirus genes

\begin{tabular}{llll}
\hline Target & Name of primer or probe ${ }^{\text {a }}$ & Sequences & $\begin{array}{l}\text { Length of PCR } \\
\text { products (bp) }\end{array}$ \\
\hline Seg4/NP4 & TIBOV-Seg4-F & 1145 \\
TIBOV-Seg4-R & 5-TGCGCTATACAGTGCAGAAG & 707 \\
Seg5/NS1 & TIBOV-Seg5-F & 5-AATCCGCCACATAAGATCC & 5-TTGCCACCAGATGCGTATCA \\
TIBOV-Seg5-R & 5-GCTGTYGTAATCAAYGCTTCCA & 855 \\
Seg9/NP6 & TIBOV-Seg9-F & 5-AAGAGCGGAAGGAAGAGAG & 99 \\
& TIBOV-Seg9-R & 5-GCTACGGTCAGGTCTACATC & \\
& TIBOV-YG-S9-F & 5-CTACGGAACGAGGAGGGGAT & \\
\hline
\end{tabular}

TIBOV, Tibet Orbivirus

a 6-Carboxy-fluorescein (FAM) and quenching group BHQ1 were conjugated on the 5' and 3' ends of the probe, respectively 
each specimen was added to a $30-\mu \mathrm{l}$ reaction volume containing PrimeSTAR HS DNA Polymerase, a high-fidelity DNA polymerase (Takara Bio), and amplified according to Duan et al. $[14,15]$.

The DNA products were sent to Kunming Shuoqing Biological Technology Company (Kunming, China) for sequencing. Cox 1 sequences were queried for best matched species in the National Center for Biotechnology Information (NCBI) and Barcode of Life Data System (BOLD) databases.

\section{Electrophoresis}

A 2.5- $\mu$ l aliquot of DNA marker AL5000 (Aidlab, Aidlab Biotechnologies Co., Ltd, Beijing, China), a 10- $\mu$ l aliquot of BHK-21 RNA or viral RNA and all of the Taq PCR products were loaded in $1 \%$ agarose gel with nucleic acid dye Goldview II (Solarbio, Beijing, China). DNA fragments were separated by electrophoresis at $100 \mathrm{~V}$ for 1 h. Fluorescent bands were screened by a Gel Doc ${ }^{\mathrm{TM}} \mathrm{XR}+$ System with Image $\mathrm{Lab}^{\mathrm{TM}}$ software (Bio-Rad, Hercules, CA, USA) and used for testing the TIBOV PCR products in virus isolates.

\section{TIBOV sequence analysis}

Amino acid sequences of NS1 proteins and VP6 proteins of 31 representative viral strains belonging to six species of Orbivirus were downloaded from the NCBI database. Sequences were aligned using the Muscle algorithm, truncated and then phylogenetic trees were constructed by the maximum likelihood (ML) algorithm with Poisson model (bootstrap $=1000$ ) using MEGA-X software [24].

\section{Results \\ Culicoides collections}

More than 18000 Culicoides, including approximately 5300 C. tainanus and 1000 C. jacobsoni, were retrieved from 23 collections (Table 1). At least 23 Culicoides species were identified. Representative wing patterns of the nine species used in isolation or qPCR testing are shown in Fig. 1.

Full data on the relative abundance and seasonality of all species collected will be published elsewhere. However, C. sumatrae was the most predominant species (32.7\%) in the latter half of 2020 while C. tainanus was the second most dominant species and appeared in all of the collections. The relative proportion of C. tainanus in each batch was $1.8-87.6 \%$, with an average abundance of $29.0 \%$ during the latter half of 2020 , reaching peak abundance (70.6-87.6\%) in the winter (Table 1). Culicoides jacobsoni, however, mainly appeared in the summer and showed peak abundance between August and October. The relative proportion of $C$. jacobsoni in each collection was $0-36.8 \%$ with an average value of $5.6 \%$ (Table 1 ).
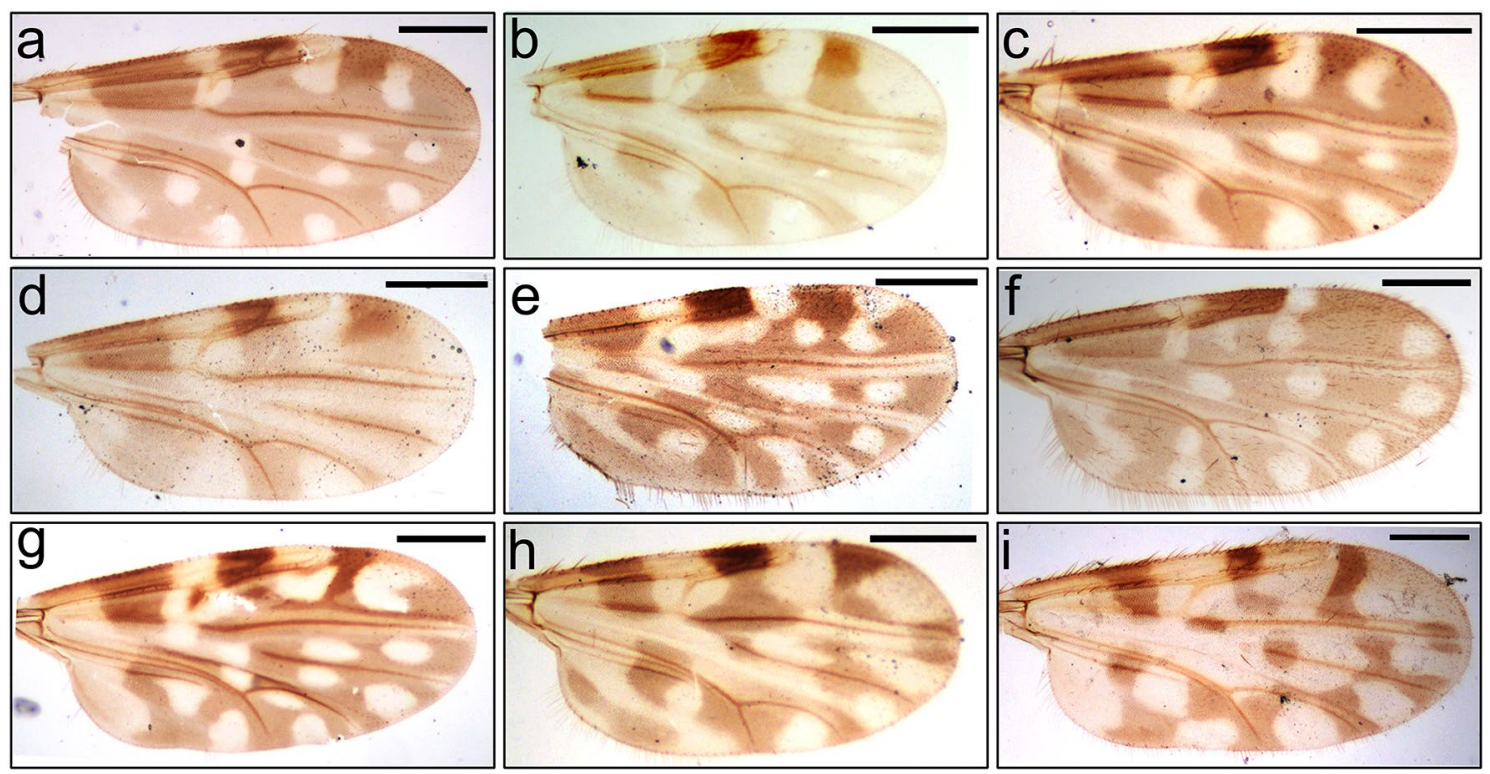

Fig. 1 Wing patterns of the major Culicoides spp. identified in this study. a C. sumatrae, b C. tainanus, c C. jacobsoni, d Culicoides (Trithecoides) spp. with a yellow scutum, e C. oxystoma, $\mathbf{f}$ C. arakawai, $\mathbf{g}$ C. insignipennis, $\mathbf{h}$ C. orientalis, i C. liui. All wings come from female specimens. Scale bar: $250 \mu m$ 
Table 3 Screening of Culicoides midges from Shizong County, Yunnan Province, China, for the presence of TIBOV by reverse transcription-quantitiative PCR

\begin{tabular}{|c|c|c|c|c|c|}
\hline \multirow[t]{2}{*}{ Species } & \multirow{2}{*}{$\begin{array}{l}\text { Midges tested } \\
\text { by RT-qPCR }(n)\end{array}$} & \multicolumn{4}{|c|}{ Pools tested by RT-qPCR (n) } \\
\hline & & Total & $\mathrm{Cq}<30$ & $30 \leq \mathrm{Cq}<35$ & $\mathrm{Cq}>35$ \\
\hline C.tainanus & 800 & 160 & 1 & 2 & 6 \\
\hline C.jacobsoni & 400 & 80 & 1 & 0 & 2 \\
\hline C. sumatrae & 300 & 60 & 0 & 0 & 0 \\
\hline C. oxystoma & 300 & 60 & 0 & 0 & 0 \\
\hline $\begin{array}{c}\text { Culicoides (Trithe } \\
\text { coides) spp. }{ }^{{ }^{a}}\end{array}$ & -120 & 24 & 0 & 0 & 1 \\
\hline C. insignipennis & 80 & 16 & 0 & 1 & 0 \\
\hline Total & 2000 & 400 & 2 & 3 & 9 \\
\hline
\end{tabular}

$\mathrm{Cq}, \mathrm{PCR}$ quantification cycle; RT-qPCR, reverse transcription-quantitiative PCR ${ }^{a}$ Culicoides (Trithecoides) spp. refers to specimens belonging to this subgenus that have a yellow scutum

\section{TIBOV and BTV RT-qPCR testing of Culicoides}

A total of 2000 biting midges were processed in 400 pools, with each pool containing five specimens of a single species, and tested for the presence of TIBOV or BTV by RT-qPCR (Table 3). Positive reactions to TIBOV RNA were observed in 14 of these pools by RT-qPCR analyses targeting TIBOV Seg10. Most of these reactions had a Cq > 30; however one pool of C. tainanus had a Cq of 28.0 and one pool of C. jacobsoni had a Cq of 28.6 (Table 3; Additional file 1: Figure S1). No pools showed any reaction to the BTV test. No evidence associating the most dominant species C. sumatrae with BTV or TIBOV was found in this study (Table 3).

Cox1 fragments were successfully amplified from the nucleic acid samples of the two TIBOV-positive pools (C. tainanus and C. jacobsoni) and from six individual C. tainanus specimens and six individual C. jacobsoni specimens collected from the same location at Shizong. The cox 1 sequences from the $C$. tainanus pool and from the C. jacobsoni pool were $100 \%$ similar with their six respective conspecific specimens. Sequences from one C. tainanus (YN/2020/T6) and one C. jacobsoni (YN/2020/J6) have been deposited in GenBank (Table 4). Comparison of sequence data with publicly available data matched the two pools of Culicoides infected by TIBOV to specimens identified as C. tainanus and C. jacobsoni, respectively. The closest matches on GenBank were two C. tainanus from Taiwan and one C. jacobsoni from South Korea, respectively (Table 4 ). The BOLD database placed our potentially infected C. tainanus (MW585344) to the Barcode Index Number (BIN) BOLD:AAI9872 containing specimens from Taiwan and Japan; while our C. jacobsoni (MW585343) belongs to BIN BOLD:AAI9869 (data not shown) which contains specimens from eight countries or regions (Malaysia, Solomon Islands, China, Reunion, Japan, Vietnam, Indonesia and Papua New Guinea), as well as from South Korea based on the $100 \%$ similarity of cox1 between the South Korea specimen (KF297817.1) and our specimen (MW585343) (Table 4) [15, 25].

\section{Isolation of viruses from Culicoides}

Virus isolation was attempted on 41 pools of midges from eight morphologically identified species and from mixed species of Culicoides belonging to the subgenus Trithecoides which were unable to be identified (Table 5). Three viruses were isolated from separate pools of C. tainanus, C. orientalis and C. jacobsoni while no virus was isolated from any of the other species (Table 5). These isolates were designated as YNV/01-1, YNV/03-2 and YNV/1714 , respectively, and submitted for molecular analysis to identify the viruses.

BHK cells inoculated with isolate YNV/17-14 from $C$. jacobsoni became intumescent and showed suspected CPEs at $24 \mathrm{~h}$ post-infection (hpi), with obvious CPEs at $48 \mathrm{hpi}$; there was almost complete cell necrosis or apoptosis at 72 hpi (Fig. 2). This observation suggests that most cells were infected by the TIBOV but that there was no obvious CPE until 48 hpi.

\section{Identification of TIBOV isolate}

The RT-qPCR analyses failed to amplify BTV or TIBOV RNA from the viruses YNV/01-1 and YNV/03-2 isolated from C. tainanus and C. orientalis, and further work is needed to identify these isolates. The virus isolated in

Table 4 Genetic similarity to sequence data in GenBank and Barcode of Life Data System of pools of C. tainanus and C. jacobsoni which produced low Cq reactions to a RT-qPCR test for TIBOV

\begin{tabular}{|c|c|c|c|c|c|}
\hline \multirow[t]{2}{*}{ Culicoides species } & \multicolumn{3}{|l|}{ GenBank } & \multicolumn{2}{|l|}{ BOLD } \\
\hline & Accession no. & Accession no. & Similarity & BIN no. & Similarity \\
\hline C.jacobsoni & MW585343 & KF297817.1 & $100 \%$ & AAl9869 & $100 \%$ \\
\hline C. tainanus & MW585344 & MK760246.1 & $99.78 \%$ & 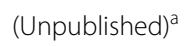 & $100 \%$ \\
\hline
\end{tabular}

BOLD, Barcode of Life Data System; NCBI, National Center for Biotechnology Information

${ }^{a}$ The best matched BIN for our C. tainanus was unpublished in BOLD 
Table 5 Virus isolation attempts from Culicoides collected from Shizong County in Yunnan Province, China

\begin{tabular}{|c|c|c|c|c|c|}
\hline Species & $\begin{array}{l}\text { Approximate number used } \\
\text { for testing }\end{array}$ & Pools ${ }^{a}$ & Cells with cytopathic effect & Isolate designation & Virus \\
\hline C.sumatrae & 1050 & $0 / 12$ & & & \\
\hline C. tainanus & 820 & $1 / 9$ & $\mathrm{C} 6 / 36$ & YNV/01-1 & Unknown \\
\hline $\begin{array}{l}\text { Culicoides (Trithecoides) } \\
\text { spp. }{ }^{\text {b }}\end{array}$ & 350 & $0 / 4$ & & & \\
\hline C. orientalis & 300 & $1 / 4$ & BHK-21, C6/36 & YNV/03-2 & Unknown \\
\hline C. arakawai & 200 & $0 / 3$ & & & \\
\hline C.jacobsoni & 200 & $1 / 2$ & BHK-21, C6/36 & YNV/17-14 & TIBOV \\
\hline C. insignipennis & 180 & $0 / 4$ & & & \\
\hline C. oxystoma & 40 & $0 / 2$ & & & \\
\hline C. liui & 20 & $0 / 1$ & & & \\
\hline Total & 3160 & $3 / 41$ & & & \\
\hline
\end{tabular}

${ }^{a}$ Values in this column are presented as positive number of pools/total number of pools

${ }^{b}$ Culicoides (Trithecoides) spp. refers to specimens belonging to this subgenus with a yellow scutum

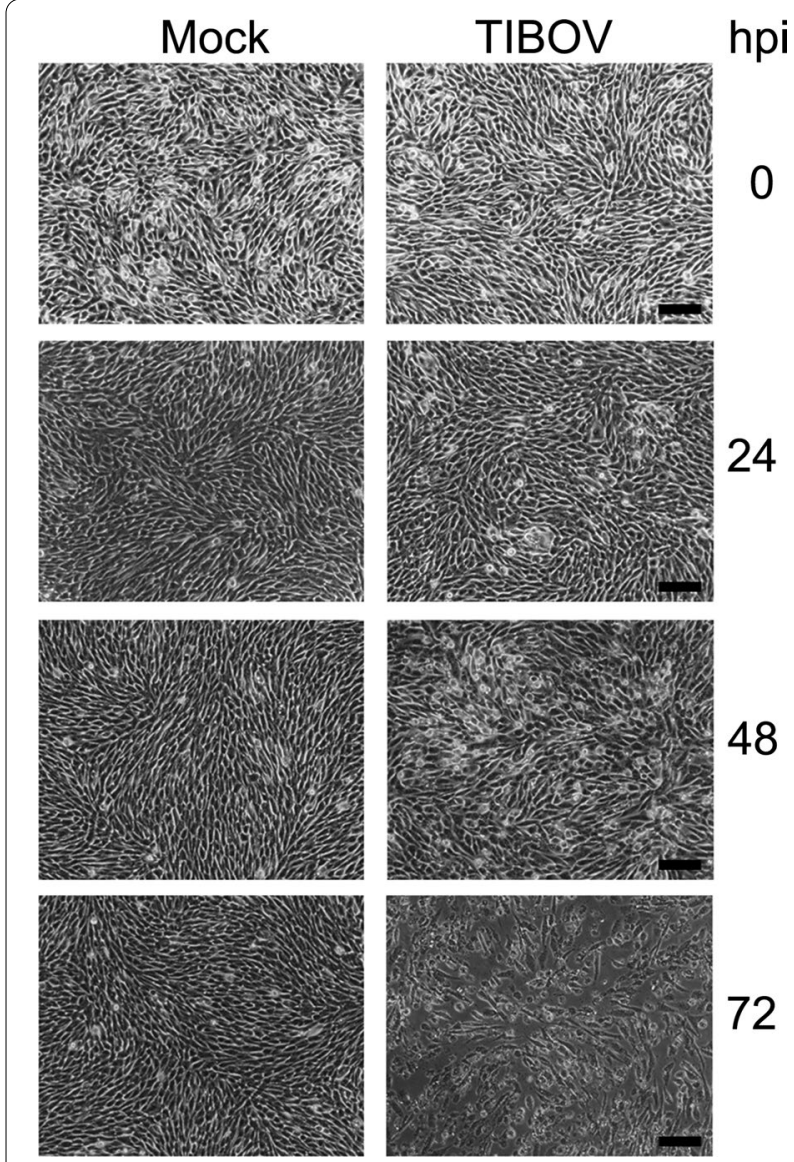

Fig. 2 Cytopathic effects caused by infection with Tibet Orbivirus (TIBOV) isolate. Mock Non-virus medium inoculated baby hamster Syrian kidney cell line BHK-21, TIBOV Tibet Orbivirus viral strain YNV/17-14-infected BHK-21 cells, hpi hours post-infection. Scale bar: $100 \mu \mathrm{m}$

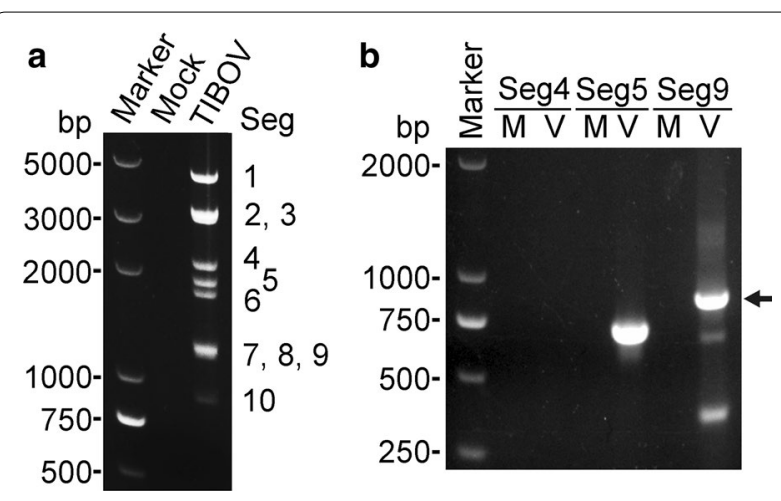

Fig. 3 Genome and PCR products of TIBOV isolate YNV/17-14. a Total RNA without cellular nucleic acids extracted from Mock (medium) and YNV/17-14-infected BHK-21 cells. b The reverse transcription-quantitative PCR products of Seg4, Seg 5 and Seg9 of TIBOV amplified from total RNA. M mock infected, VTIBOV infected. Arrow identifies the target product of Seg 9

BHK cells from the single pool of C. jacobsoni, YNV/1714 (Additional file 2: Table S1), however, produced a positive reaction to the TIBOV RT-qPCR.

Electrophoresis of isolate YNV/17-14 revealed ten discrete segments with a 3-3-3-1 pattern consistent with BTV and TIBOV (Fig. 3a). Three pairs of primers specific for TIBOV genes successfully amplified Seg5 and Seg9 of isolate YNV/17-14, confirming it as a strain of TIBOV. The failure to amplify Seg4 might be caused by intraspecific sequence differences between the primers and template (Fig. 3b).

The PCR products of Seg5 and Seg9 from isolate YNV/17-14 and from the suspected positive pool of C. tainanus midges labeled KMV583 (Table 3; Additional file 1: Figure S1) were sequenced and found to 
match TIBOV genes registered in GenBank. These four sequences of TIBOV YNV/17-14 (MW436463, MW436464) and KMV583 (MW465962, MW465963) have been lodged with GenBank (Additional file 2: Table S1). A phylogenetic tree created from nonstructural protein 1 (NS1) proteins (usually encoded by Seg5) from 23 viruses belonging to six species of Orbivirus showed that our two virus strains were clustered with a group of four strains of TIBOV reported previously, and the branch distances suggested that TIBOV is closely related to epizootic haemorrhagic disease virus (EHDV) and BTV, but distantly related to Yunnan Orbivirus (YUOV) (Fig. 4). A phylogenetic tree based on VP6 proteins (usually encoded by Seg9) produced a similar result (Additional file 3: Figure S2). All sequences used in our phylogenetic trees were downloaded from GenBank, and their accession numbers are listed in Additional file 2: Table S1.

\section{C-ELISA test for cattle sera}

All the serum samples were negative for BTV antibodies based on the results from the C-ELISA. TIBOV antibodies could not be detected in cattle sera because the reagents required were not available.

\section{Discussion}

Tibet Orbivirus (TIBOV), a novel Orbivirus, was discovered, isolated, completely sequenced and identified relatively recently $[6-9,26]$, but has yet to be registered by the International Committee on Taxonomy of Viruses (2020) [2]. So far, the virus is only known from China (Additional file 2: Table S1) [6-9, 26, 27] and Japan [28], and its vertebrate hosts are likely to include cattle, Asian buffalo and goats [9]. There is currently no information on serotypes or genotypes for TIBOV, although limited phylogenetic analysis suggests that multiple serotypes or genotypes do exist (Fig. 4; Additional file 3: Figure S2) [7, 26].

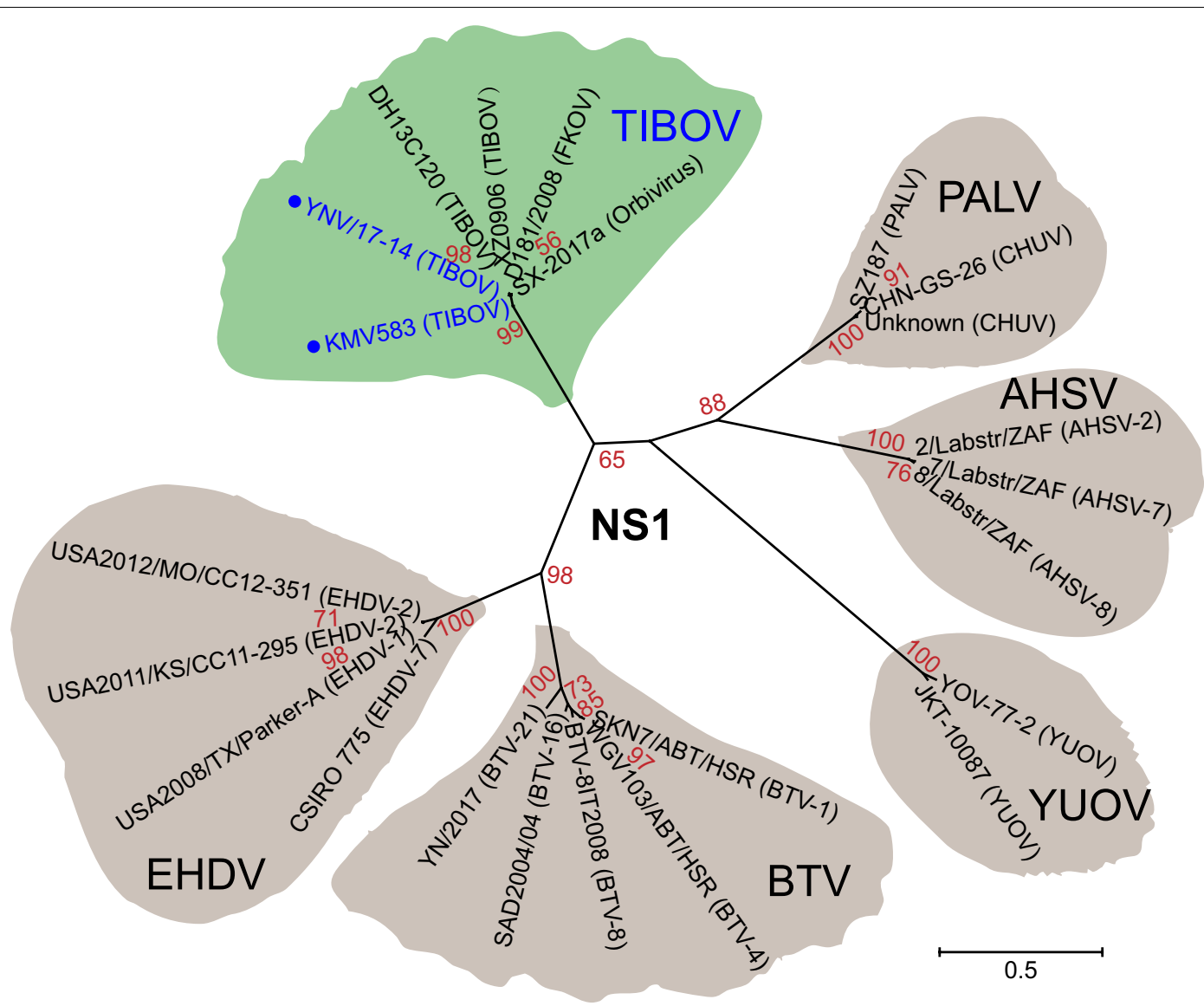

Fig. 4 Phylogenetic tree of representative Orbivirus based on non-structural protein 1 (NS1) amino acids. The tree is constructed using the maximum likelihood algorithm with Poisson model (bootstrap $=1000$ ); bootstrap values $<50 \%$ are omitted. For each virus, strain name, species and serotype are provided. Detailed information of each virus is listed in Additional file 2: Table S1 
Culicoides spp. are vectors of at least 50 species of arbovirus [12, 13], including EHDV, AHSV and Palyam virus (PALV) $[8,12,13,29,30]$, and thus an association between Culicoides and TIBOV is not surprising. The isolation of TIBOV from $C$. jacobsoni provides evidence that this species satisfies one of the criteria proving it to be a vector of TIBOV. Culicoides jacobsoni was one of the predominant species in the collections made during the summer in the cattle shed at Shizong, which supports its potential importance as a vector of this virus although more extensive studies on both the seasonal prevalence of TIBOV and the relative abundance of species of Culicoides are warranted to support this observation at Shizong. The taxonomy of C. jacobsoni is complex, with several potential cryptic species reported by Gopurenko et al. [31]; however, the haplotype collected at Shizong belongs to a distinct DNA barcode cluster (BIN BOLD:AAI9869) that is widespread in Asia and extends into the Pacific. Regional areas where C. jacobsoni (particularly strain BOLD:AAI9869) overlap with host mammals should be monitored for the presence of TIBOV to determine if this virus is present throughout the insect's known distribution. If so, this may lend further support to the labeling of $C$. jacobsoni as a vector of TIBOV.

Seasonal abundance data suggest that $C$. tainanus populations peak during colder times of the year, a finding which is consistent with the largely temperate distribution of this midge species in Asia [14, 16, 17]. However, C. jacobsoni appears to prefer warmer weather, which is also consistent with the known distribution of this species in southern Asia and the Pacific [15-17, 31].

Traditionally, evidence of infection of Culicoides with orbiviruses was provided by the isolation of virus in the laboratory. However, keeping viruses viable in fieldcollected specimens is laborious as they are sensitive to any number of factors likely to occur between collection of the specimens and use in virus isolation techniques, such as overheating of samples, delays in transporting specimens and contamination with non-specific bacteria or fungi. Recent advances in PCR technology has allowed field-collected specimens preserved in ethanol to be screened for the presence of virus using the $\mathrm{Cq}$ value determined in RT-PCR analyses to distinguish specific and non-specific reactions, thereby allowing reliable interpretation of results [14, 15, 32-36]. Calibration of the test, however, requires an assessment of the threshold Cq value for each virus to enable insects to be distinguished in terms of those in which virus has replicated and those which either retain residual virus from an infected blood meal or have a non-specific reaction in the test. Thus far this calibration has only been conducted using BTV infection in Culicoides [32, 34-37], which has allowed for the identification of novel potential vector species of BTV in China [14, 15]. Indeed, the bimodal pattern of reactions observed with field-collected specimens reported by Duan et al. [14, 15], where reactions were observed with Cq values either $<25$ or $>30$, provides support that the laboratory-based results of Van Der Saag et al. [32] and Veronesi et al. [37] are applicable to field-collected midges. Extrapolation of this result to other viruses is difficult as the level of viremia in the insect may vary, which could alter the Cq value on which determination of infection of the insect is based. Unfortunately, the RT-qPCR assays used for TIBOV have not yet been calibrated to allow reliable identification of insects in which virus has replicated; however, a bimodal pattern of $\mathrm{Cq}$ values was observed in this study, with two reactions showing a $\mathrm{Cq}$ value of around 28 and the remainder showing a $\mathrm{Cq}$ value of $>32.8$ (Table 3; Additional file 1: Figure $\mathrm{S} 1$ ). The late $\mathrm{Cq}$ emergence here is unlikely to be caused by the formation of primer-dimer because the primers and probe for TIBOV RT-qPCR were designed well. Temporary conservation of midges in PBS within $48 \mathrm{~h}$ before sorting may be one of factors that resulted in relatively high $\mathrm{Cq}$ values of the positive samples for TIBOV detection in this study, since all of the midges used for BTV detection in our previous reports were kept in $70-90 \%$ ethanol all of the time $[14,15]$. The fact that one of these reactions with a low Cq value was obtained from a small pool of C. jacobsoni, a species from which viable virus was also isolated, suggests that a $\mathrm{Cq}$ value $<29$ may possibly indicate that specimens were infected with virus. Further support for the potentially positive result from the RT-qPCR lies in the successful amplification of seg5 and seg9 from the PCR product obtained from the pool of C. tainanus and the matching of these gene sequences to isolates of TIBOV. If the use of RT-qPCR to detect infected insects is validated in laboratory studies, then this technique provides evidence that TIBOV has also been detected in field-collected specimens of $C$. tainanus, thus satisfying one of the criteria proving this species to be a vector of TIBOV. Should this haplotype of this species be proven to be a vector of TIBOV, then its wide distribution, including Taiwan and Japan, suggests that TIBOV should have a similarly wide distribution.

No evidence of infection with BTV was detected from the Culicoides in this study, which was supported by the negative result of BTV antibodies in sampled cattle. This lack of BTV infection may be caused by the relatively low livestock density in the farm studied, although Shizong County is a prevalent area of BTV. 


\section{Conclusions}

The detection and isolation of TIBOV in C. jacobsoni provides the first evidence of the vector status of this midge species for TIBOV and suggests that TIBOV might be more widely distributed than currently known. RT-qPCR results for $C$. tainanus may additionally have detected TIBOV in this species, but more work is required to validate this test. Once validated, this test will prove a useful tool in future studies of the ecology of this virus.

\begin{abstract}
Abbreviations
AHSV: African horse sickness virus; BIN: Barcode Index Number; BTV: Bluetongue virus; BLAST: Basic local alignment search tool; BOLD: Barcode of Life Data System; cox1: Cytochrome c oxidase subunit 1; CPE: Cytopathic effect; Cq Quantification cycle; EEV: Equine encephalosis virus; EHDV: Epizootic haemorrhagic disease virus; hpi: Hours post-infection; MEM: Minimum essential medium; ML: Maximum likelihood; NCBI: National Center for Biotechnology Information; NCS: Newborn calf serum; NS1: Non-structural protein 1; PALV: Palyam virus; RT-qPCR: Reverse transcription quantitative PCR; TIBOV: Tibet Orbivirus; VP6: Viral protein 6; YUOV: Yunnan Orbivirus.
\end{abstract}

\section{Supplementary Information}

The online version contains supplementary material available at https://doi. org/10.1186/s13071-021-04899-9.

Additional file 1: Figure S1. Culicoides (Trithecoides) spp. refers to specimens belonging to this subgenus with a yellow scutum. Cq values from RT-qPCR tests for TIBOV from specimens referable to four species of Culicoides. Each point represents the $\mathrm{Cq}$ value of a pool composed of five conspecific specimens. Pools with Cq values $<30$ are labeled red.

Additional file 2: Table S1. Amino acid sequences of orbiviruses used in phylogenetic analysis.

Additional file 3: Figure S2. Phylogenetic tree of representative Orbivirus based on VP6 amino acids. The tree is constructed by the ML algorithm with Poisson model (bootstrap $=1000$ ); bootstrap values $<50 \%$ are omitted. For each virus, strain name, species and serotype are provided. Detailed information of each virus is listed in Additional file 2: Table S1.

\section{Acknowledgements}

We are thankful to Heng Yang (Yunnan Animal Science and Veterinary Institute, Kunming, Yunnan Province, China) for his kind gift of the primers targeting TIBOV Seg4.

\section{Authors' contributions}

YLD: PCR and sequencing for genes, mounting specimens, data analysis, article writing. ZXY: isolated virus and performed RT-qPCR. GB: advice on insect identification by morphology, interpretation of results and article proofreading. LL: study design, Culicoides collection, sorting and digestion. All authors read and approved the final manuscript.

\section{Funding}

The present study was funded by the Foreign Experts Projects of Yunnan Province (YNZ2020015 and YNZ2019002).

\section{Availability of data and materials}

Data supporting the conclusions of this article are provided within the article. Raw data are available from the corresponding author upon request. The newly generated sequences were submitted to the GenBank database under the accession numbers: cox1 sequences (MW585343 and MW585344); TIBOV Seg5 (MW436463, MW465962) and Seg9 (MW436464, MW465963).

\section{Declarations}

Ethics approval and consent to participate

The process of blood collections from animals was approved by the Ethics Committee of Yunnan Animal Science and Veterinary Institute (YASVI/2020/ Li-001).

\section{Consent for publication}

Not applicable.

\section{Competing interests}

The authors declare that they have no competing interests.

\section{Author details}

${ }^{1}$ Yunnan Tropical and Subtropical Animal Virus Diseases Laboratory, Yunnan Animal Science and Veterinary Institute, Kunming, Yunnan, China. ${ }^{2}$ Research Institute for the Environment and Livelihoods, Charles Darwin University, Darwin, NT, Australia. ${ }^{3}$ Department of Agriculture, Water and the Environment, Darwin, NT, Australia.

Received: 11 May 2021 Accepted: 27 July 2021

Published online: 28 August 2021

References

1. Schiff $L A$, Nibert ML, Tyler KL. Orthoreoviruses and their replication. In: Fields BN, Knipe DM, Howley PM, editors. Fields virology. 5th ed. Philadelphia: Wolters Kluwer Health/Lippincott Williams \& Wilkins; 2007. p. 2388-471.

2. International Committee on Taxonomy of Viruses (ICTV). Virus taxonomy: 2019 release. EC51. https://talk.ictvonline.org/taxonomy/. Accessed 27 Jan 2021.

3. Lefkowitz EJ, Dempsey DM, Hendrickson RC, Orton RJ, Siddell SG, Smith DB. Virus taxonomy: the database of the International Committee on Taxonomy of Viruses (ICTV). Nucleic Acids Res. 2018;46:D708-17.

4. WHO Scientific Group. Arthropod-borne viruses. World Health Organization Technical Report Series, vol. 12, no. 219. Geneva: World Health Organization; 1961

5. WHO Scientific Group. Arboviruses and human disease. World Health Organization Technical Report Series, vol. 18, no. 369. Geneva: World Health Organisation; 1967

6. Li M, Zheng Y, Zhao G, Fu S, Wang D, Wang Z, et al. Tibet Orbivirus, a novel orbivirus species isolated from Anopheles maculatus mosquitoes in Tibet, China. PLoS One. 2014;9:e88738.

7. Xing S, Guo X, Zhang X, Zhao Q, Li L, Zuo S, et al. A novel mosquitoborne reassortant orbivirus isolated from Xishuangbanna, China Virol Sin. 2017:32:159-62.

8. Lei W, Guo X, Fu S, Feng Y, Nie K, Song J, et al. Isolation of Tibet Orbivirus, TIBOV, from Culicoides collected in Yunnan, China. PLoS One. 2015;10:e0136257.

9. Wang J, Li H, He Y, Zhou Y, Xin A, Liao D, et al. Isolation of Tibet Orbivirus from Culicoides and associated infections in livestock in Yunnan, China. Virol J. 2017;14:105.

10. Orbiviruses Roy P. In: Fields BN, Knipe DM, Howley PM, editors. Fields virolology. 5th ed. Philadelphia: Wolters Kluwer Health/Lippincott Williams \& Wilkins; 2007. p. 2541-68.

11. Toit RMD. The transmission of blue-tongue and horse-sickness by Culicoides. Onderstepoort J Vet Sci Anim Ind. 1944;19:7-16.

12. Mellor PS, Boorman J, Baylis M. Culicoides biting midges: their role as arbovirus vectors. Annu Rev Entomol. 2000:45:307-40.

13. Meiswinkel R, Venter GJ, Nevill EM. Vectors: Culicoides spp. In: Coetzer JAW, Tustin RC, editors. Infectious diseases of livestock, vol. 1. 2nd ed. Oxford: Oxford University Press; 2004. p. 93-136.

14. Duan YL, Bellis G, Li L, Li HC, Miao HS, Kou ML, et al. Potential vectors of bluetongue virus in high altitude areas of Yunnan Province, China. Parasites Vectors. 2019;12:464.

15. Duan $Y L$, Li L, Bellis G, Yang ZX, Li HC. Detection of bluetongue virus in Culicoides spp. in southern Yunnan Province, China Parasites Vectors. $2021 ; 14: 68$ 
16. Liu JH, Liu GP, Liu ZJ, Yan G, Hao BS, Zhao TS, et al. Ceratopogonidae: Culicoides. In: Yu YX, editor., et al. Ceratopogonidae of China, vol. 2. Beijing: Military Medical Science Press; 2005. p. 816-1323 (in Chinese).

17. Wirth WW, Hubert AA. The Culicoides of southeast Asia (Diptera: Cerat opogonidae). Mem Am Entomol Institute. 1989;44:1-509.

18. Bellis GA. Key to females of economically important species of Culicoides subgenus Avaritia from southern Asia and Australasia using characters visible under a stereomicroscope. https://www.gnatwork.ac.uk/sites/ gnatwork/files/content/attachments/2020-04-24/Economic\%20Avaritia\% 20Key.pdf. Accessed 24 Apr 2020.

19. Kato T, Shirafuji H, Tanaka S, Sato M, Yamakawa M, Tsuda T, et al. Bovine arboviruses in Culicoides biting midges and sentinel cattle in southern Japan from 2003 to 2013. Transbound Emerg Dis. 2016;63:e160-72.

20. Duan YL, Miao HS, Liao F, Kou ML, Li ZH, Wang Z, et al. The serologic investigation and viral isolation of bluetongue virus in Shangri-La in southwest China. Transbound Emerg Dis. 2019;66:2353-61.

21. Russell D, Sambrook J. Extraction, purification, and analysis of mRNA from eukaryotic cells. In: Argentine J, editor. Molecular cloning: a laboratory manual. 3rd ed. Long Island: Cold Spring Harbor Laboratory Press; 2001. p. 141-60.

22. Yang ZX, He YW, Xie JR, Li ZH, Li ZR, Liao DF, et al. Establishment and application of real-time fluorescent quantitative RT-PCR and routine RTPCR for detection of Tibet Orbivirus. Chinese Vet Sci. 2020;50:1365-72 (in Chinese).

23. Hofmann M, Griot C, Chaignat V, Perler L, Thur B. Bluetongue disease reaches Switzerland. Schweiz Arch Tierheilkd. 2008;150:49-56 (in German).

24. Hall BG. Building phylogenetic trees from molecular data with MEGA. Mol Biol Evol. 2013;30:1229-35.

25. Mathieu B, Garros C, Balenghien T, Candolfi E, Delecolle JC, Cetre-Sossah C. A phylogenetic analysis of the biting midges belonging to Culicoides Latreille (Diptera: Ceratopogonidae) subgenus Avaritia using molecular data. Parasites Vectors. 2020;13:243.

26. Wu D. Fengkai Orbivirus, a new genotype of Tibet Orbivirus isolated from pooled Culex fatigan mosquitoes in 2008, in Guangdong, China. In: Anonymous, editors. Workshop for control of EID. Guangzhou; 2015.

27. Xia H, Wang Y, Atoni E, Zhang B, Yuan Z. Mosquito-associated viruses in China. Virol Sin. 2018:33:5-20.
28. Suda Y, Murota K, Shirafuji H, Yanase T. Genomic analysis of putative novel serotypes of Tibet orbivirus isolated in Japan. Arch Virol. 2021;166:1151-6.

29. Ruder MG, Stallknecht DE, Howerth EW, Carter DL, Pfannenstiel RS, Allison $A B$, et al. Effect of temperature on replication of epizootic hemorrhagic disease viruses in Culicoides sonorensis (Diptera: Ceratopogonidae). J Med Entomol. 2015;52:1050-9.

30. Wilson A, Mellor PS, Szmaragd C, Mertens PP. Adaptive strategies of African horse sickness virus to facilitate vector transmission. Vet Res. 2009:40:16.

31. Gopurenko D, Bellis GA, Yanase T, Wardhana AH, Thepparat A, Wang J, et al. Integrative taxonomy to investigate species boundaries within Culicoides (Diptera: Ceratopogonidae): a case study using subgenus Avaritia from Australasia and Eastern Asia. Vet Ital. 2015;51:345-78.

32. Van der Saag M, Nicholas A, Ward M, Kirkland P. Evaluation of in vitro methods for assessment of infection of Australian Culicoides spp. with bluetongue viruses. Vet Ital. 2015;51:335-43.

33. Van Der Saag MR, Ward MP, Kirkland PD. Application of an embryonated chicken egg model to assess the vector competence of Australian Culicoides midges for bluetongue viruses. Med Vet Entomol. 2017;31:263-71.

34. Aguero M, Gomez-Tejedor C, Angeles Cubillo M, Rubio C, Romero E, Jimenez-Clavero A. Real-time fluorogenic reverse transcription polymerase chain reaction assay for detection of African horse sickness virus. J Vet Diagn Invest. 2008;20:325-8.

35. Goffredo M, Savini G, Quaglia M, Molini U, Federici V, Catalani M, et al. Orbivirus detection from Culicoides collected on African horse sickness outbreaks in Namibia. Vet Ital. 2015;51:17-23.

36. de Waal T, Liebenberg D, Venter GJ, Mienie CM, van Hamburg H. Detection of African horse sickness virus in Culicoides imicola pools using RT-qPCR. J Vector Ecol. 2016;41:179-85.

37. Veronesi E, Antony F, Gubbins S, Golding N, Blackwell A, Mertens PP, et al. Measurement of the infection and dissemination of bluetongue virus in Culicoides biting midges using a semi-quantitative RT-PCR assay and isolation of infectious virus. PLoS One. 2013;8:e70800.

\section{Publisher's Note}

Springer Nature remains neutral with regard to jurisdictional claims in published maps and institutional affiliations.
Ready to submit your research? Choose BMC and benefit from:

- fast, convenient online submission

- thorough peer review by experienced researchers in your field

- rapid publication on acceptance

- support for research data, including large and complex data types

- gold Open Access which fosters wider collaboration and increased citations

- maximum visibility for your research: over 100M website views per year

At BMC, research is always in progress.

Learn more biomedcentral.com/submissions 